\title{
BEYOND GENERAL PRONOUNCEMENTS: A JUDICIAL APPROACH TO SECTION 27 OF THE CHARTER [forthcoming?]
}

\author{
VERN W. DaRE
}

The author provides a thorough synthesis and evaluation of the multicultural provision in the Charter. He begins by exploring possible definitions of multiculturalism, deriving his concept from various academic disciplines as well as federal policies. The difficulty on settling for a comprehensive definition of multiculturalism is manifest in the mixed signals within both the federal government's Multiculturalism Policy of 1971 and the subsequent legislation, the Canadian Multiculturalism Act He then selectively surveys the judicial approaches taken to s. 27. Current treatment is sparse and any discussion of the multicultural section is largely subsumed in a general discussion of other sections of the Charter such as ss. I and 2. Through this survey, he demonstrates the limited, restricted reading of s. 27 accorded by the judiciary. Finally, the author considers the inherent limits of the section; he compares it to a similar provision in Quebec's human rights legislation, general liberal theory and possible conflicts between s. 27 and other precepts of Canadian society, specifically bilingualism. He concludes that s. 27 must be expanded within its negative role, protecting individual communities and individuals from the acts of others rather than being used as a tool to entrench positive or collective rights of ethnic groups.
L'auteur fournit une synthèse et une évaluation approfondies des dispositions multiculturelles de la Charte. Il commence par explorer les définitions possibles du multiculturalisme en s'inspirant de plusieurs disciplines ainsi que des politiques fédérales. La difficulté d'adopter une définition globale du multiculturalisme est évidente si l'on en juge par le contenu mitigé de la Politique de multiculturalisme de 1971 et de la Loi sur le multiculturalisme canadien qui a suivi. Il étudie ensuite les approches judiciaires envers l'art. 27. $L$ 'attitude actuelle est réservée et toute discussion de l'article en question est largement subsumée dans une discussion générale traitant d'autres articles de la Charte, les art. I et 2 notamment. Dans cette étude, l'auteur démontre l'interprétation limitée que le système judiciaire fait de l'art. 27. Finalement, il considere les limites inhérentes de l'article, l'examine à la lumière d'une disposition analogue de la législation sur les droits de la personne au Québec, en regard de la théorie libérale générale, et relève des conflits possibles entre l'art. 27 et d'autres préceptes de la société canadienne - plus précisément le bilinguisme. II conclut que la portée de l'art. 27 doit être étendue au sein de ce rôle négatif, en vue de protéger les collectivités individuelles et les individus des actes d'autrui, plutôt que de servir à enchâsser les droits positifs ou collectifs des groupes ethniques.

TABLE OF CONTENTS

I. INTRODUCTION ................... 552

II. THE MEANING OF MULTICULTURALISM $\ldots \ldots \ldots \ldots \ldots 555$

III. SOME JUDICIAL APPROACHES TO SECTION $27 \ldots \ldots \ldots .559$

A. LEADING CASE LAW UNDER SECTION $27 \ldots \ldots \ldots .561$

B. THE BEGINNINGS OF AN APPROACH

UNDER SECTION $27(?) \ldots \ldots \ldots \ldots \ldots \ldots \ldots \ldots . \ldots 64$

IV. A MULTICULTURAL APPROACH

UNDER SECTION $27 \ldots \ldots \ldots \ldots \ldots \ldots \ldots \ldots$

A. TEXTUAL LIMITS OF SECTION $27 \ldots \ldots \ldots \ldots \ldots 7$

B. SECTION 27, MINORITY RIGHTS AND

THE LIBERAL INDIVIDUALIST APPROACH $\ldots \ldots \ldots 568$

With the Manitoba Law Reform Commission. The helpful comments of Aaron Berg, Dale Gibson and Ken Tyler were very much appreciated. The views expressed in this article, however, are those of the writer. 


\section{SECTION 27'S HIERARCHICAL STATUS $\ldots \ldots \ldots \ldots \ldots$ 571 \\ v. CONCLUSION ..................... 572}

\section{INTRODUCTION}

The judicial development of s. 27 of the Charter' remains embryonic despite more than a decade of consideration. With few cited cases, limited analysis, and general pronouncements shaping much of the jurisprudence, ${ }^{2}$ the courts have avoided grappling with the intricacies of the multicultural provision. The result of this irresolute treatment is a quixotic section, ambiguous in nature and lacking a multicultural approach.

This paucity of jurisprudence distinguishes s. 27 from many other Charter provisions. ${ }^{3}$ Several reasons have been advanced to explain the courts' reluctance to

Canadian Charter of Rights and Freedoms, Part I of the Constitution Act, 1982, being Schedule B to the Canada Act 1982 (U.K.), 1982, c. 11 [hereinafter the Charter], s. 27: "This Charter shall be interpreted in a manner consistent with the preservation and enhancement of the multicultural heritage of Canadians." (S.C.C.) [hereinafter Fosty]; and Saskatchewan (Human Rights Commission) v. Bell, [1994] 5 W.W.R. 458 (Sask. C.A.) [hereinafter Bell]. The former concerned the exclusion of evidence based on religious communication. The Supreme Court of Canada used s. 27 in conjunction with s. 2(a) (freedom of religion) to find a "non-denominational" approach to the exclusionary rule. Under this approach the Court refused to limit the application of the rule to formal confessions made to ordained priests or ministers. Broader based communications were subject to the Court's scrutiny. Section 27 directed this "non-denominational" approach according to the Court. Yet no actual analysis of s. 27 was provided. Despite the significance of the provision to a "non-denominational" approach, the extent of the Court's analysis was a reference to s. 27 as a "general interpretative statement."

In Bell, s. 27 was applied under the s. 1 "reasonable limits" analysis to uphold a provision of the Saskatchewan Human Rights Code, S.S. 1979, c. S-24.1. The provision prohibited discriminatory practices and materials which ridiculed or belittled any group because of race or religion. The practice and material in question concerned the sale of "not allowed" stickers aimed at particular ethnic groups. The lower court held the provision to be a reasonable limit on expression and referred to s. 27 to support the proposition that Canadian society is equally committed to all cultures. Again no actual analysis of s. 27 was provided. On appeal, the substantive part of the decision was upheld, but with no reference at all to $\mathrm{s}$. $27 !$ This is somewhat surprising given that the case had everything to do with multiculturalism.

The well reasoned principles announced by the judiciary for several sections of the Charter have simply not materialized with respect to s. 27. For example, s. 1 has been elaborated in $R$. v. Oakes, [1986] 1 S.C.R. 103; s. 15 in Andrews v. Law Society of B.C., [1989] I S.C.R. 143 [hereinafter Andrews], and so on. Even outside the provisions of the Charter, such as with s. 35, the court has outlined a framework of analysis in $R$. v. Sparrow, [1990] 1 S.C.R. 1075. In these landmark decisions, the court tackled the complex and divisive legal, philosophical and policy issues under the concepts of "reasonable limits," "equality," and "aboriginal rights"; and pronounced an approach or analytical framework to the particular section. This has been largely missing under s. 27. Most courts have been reluctant to acknowledge the application of the section. Even when cited, there has been little in-depth analysis. Judicial avoidance of the issues raised by the provision has characterized much of the case law. 
give fuller meaning to the section. For some, the section is merely symbolic. ${ }^{4}$ For others it is the "persistent ambiguities," ${ }^{5}$ the "political genesis," 6 or the "limitless"7 or "boundless"8 nature of the section that curtails its effectiveness. Others cite limited resources and funds to implement multiculturalism as reasons for judicial restraint under s. 27.9 An increasing perception that the multicultural concept is an affront to national unity and identity may be another consideration. ${ }^{10}$ Others justify the limited significance of 5.27 by referring to its declarative ${ }^{11}$ or interpretative ${ }^{12}$ status. Some

4 E.g. Professor P.W. Hogg stated that s. 27 "may prove to be more of a rhetorical flourish than an operative provision," in Canada Act 1982: Annotated (Toronto: Carswell, 1982) at 72; and in the latest edition of his general treatise on the Constitution, Constitutional Law of Canada, 3d ed. (Toronto: Carswell, 1992), he has not included a single section to examine the multicultural provision. Professor D. Gibson has rejected this narrow view or "definitional shrinkage" in "Section 27 of the Charter: More than a 'Rhetorical Flourish'" (1990) 28 Alta. L. Rev. 589, and observes (ibid. at 592) that there "has already been enough judicial use made of s. 27 to demonstrate that Professor Hogg has seriously underestimated the importance of the provision." See also D. Gibson, "The Deferential Trojan Horse: A Decade of Charter Decisions" (1993) 72 Can. Bar Rev. 417 at 436.

S J. Jaworsky, A Case Study of the Canadian Federal Government's Multiculturalism Policy (M.A. Thesis, Carleton University, 1979) [unpublished]. The "persistent ambiguities" of the multicultural principle concern questions of the relationship of multiculturalism to dualism, language, group rights and Quebec. More specifically, the questions left unresolved by these "persistent ambiguities" include: the relationship of language and culture and what constraints multiculturalism might experience within an English-French bilingual framework; the place of group rights in the protection of the multicultural principle; and the role of multiculturalism in Quebec.

6 D. Bottos, "Multiculturalism: Section 27's Application in Charter Cases Thus Far" (1988) 26 Alta. L. Rev. 621 at 632. The "political genesis" of the provision refers to the "last minute" nature of the adoption of s. 27, its inclusion in the Constitution as a "political afterthought" in response to lobby pressure by various ethnic groups and its subsequent importance for these groups as reflecting their status in Canada. Bottos links the judicial treatment of 5.27 to its "political genesis" when he states (ibid. at 632): "It is more likely that $\mathrm{s.} 27$ will be provided more respect in the future when the political background of the section's inclusion will be less at the forefront of the minds of the courts."

7 Ibid. The author points out that "the courts might not know how to deal with s. 27 yet [given] the potential power that it, in combination with ss. 2 and 15, could have."

8 H.R. Hosein, "Distorted: A View of Canadian Multiculturalism Within a Bilingual Framework" (1991) 30 Alta. L. Rev. 597 at 599. The author points out: "A major criticism of multiculturalism is that the concept of complying with it knows no bounds. How far do we go in accommodating cultural difference?" The author queries whether it includes provision of public education in any language upon demand, translating legislation into languages other than English and French, or modifying "culture-neutral" institutions to accommodate cultural diversity.

$9 \quad$ Ibid. at 620 .

10 As we embark upon yet another navel gazing process of national unity debates in 1994-95, this viewpoint, including the role of "hyphenated-Canadianism" is likely to receive some attention. Indeed, it has recently received national attention largely as a response to Neil Bissoondath's bestseller, Selling Illusions: The Cult of Multiculturalism in Canada (Toronto: Penguin Books, 1994).

1 Some courts have treated s. 27 as more a declarative or a preambular reference than interpretive. See supra note 6 .

12 This view is rejected by Professor Gibson, supra note 4 at 592: "Although s. 27 is no more than an interpretative aid, it should not be denigrated on that account. Interpretation, whether of statutes, contracts, common law principles, or constitutional rights, is central to the judicial function." Some courts, however, have not been sympathetic to this assessment. For example, in Roach v. Canada (1994), 113 D.L.R. (4th) 67, the Federal Court of Appeal refused to apply s. 27 on the ground that 
view its collective nature or thrust as contradictory to liberal theory and the individual rights protected under the Charter. ${ }^{13}$ Whatever the reason, s. 27 has not been treated as creating a truly justiciable right.

To remedy the situation, it is argued in this article that the courts should take a more active role in shaping s. 27 , that the meaning of culture and multicultural heritage should be given closer attention, and that the competing policies underlying the provision should be considered. Part II examines various meanings of the provision, Part III reviews the more sophisticated applications of the provision in a few cases, ${ }^{14}$ and Part IV advances a possible multicultural approach under the section.

A starting point to the approach in Part IV is to examine the provision in a wider context of minority rights which are limited under Canadian constitutionalism. Minority rights ${ }^{15}$ are central to a policy of diversity or pluralism and are achieved through negative and positive rights, or the equal treatment of the members of the minority group and the adoption of special provisions designed to maintain and promote the group's specific characteristics. ${ }^{16}$ Understood in this dual capacity as being capable of supporting both individual and collective rights, $s .27$ falls short of being a "true" minority right. In its absolute or true form, multiculturalism as a minority right connotes institutional completeness, collective rights and group maintenance. Under the Canadian Constitution, however, its form has been compromised by other preferred constitutional principles, such as dualism. ${ }^{17}$ Only official minorities are guaranteed

it could not be pleaded as a freestanding provision. The Court's reasoning is indicative of the view that s. 27 is of limited significance due to its interpretative status. The Court held: "It is not necessary to plead this provision. Nor is it a substantive provision that can be violated. Since $s$. 27 does not protect a particular right or freedom, it being relevant only as an aid to interpretation, it should not be pleaded in the way it has been." (ibid. at 95).

13 Supra note 8 at 601-603.

14 It is not the purpose of this article to provide a detailed summary and analysis of the case law under s. 27. This has been provided elsewhere; see e.g. supra note 6; Gibson, supra note 4; V.W. DaRe, Multiculturalism, Linguistic Dualism and the Distinct Society: Unresolved Community Issues under the Canadian Constitution (LL.M. Thesis, University of Toronto, 1990) [unpublished].

F. Capotorti, Study on the Rights of Persons Belonging to Ethnic, Religious and Linguistic Minorities (New York: United Nations, 1979). He proposed the following definition of "minority" at 96:

A group numerically inferior to the rest of the population of a state, in a non-dominant position, whose members, being nationals of the state, possess ethnic, religious or linguistic characteristics differing from those of the rest of the population, and have, if only implicitly, a sense of solidarity, directed towards preserving their culture, traditions, religion or language.

16 Ibid. Capotorti states at 41 , that the prevention of discrimination, on the one hand, and the implementation of special measures to protect minorities, on the other, are merely two aspects of the same problem: that of defending fundamental human rights in a pluralist society. See also 3 . Woehrling, "Minority Cultural and Linguistic Rights and Equality Rights in the Canadian Charter of Rights and Freedoms" (1985) 31 McGill L.J. 50 at 53.

1 For an account of the limits imposed on multiculturalism by official bilingualism, see supra note 8; Professor J.E. Magnet explains these limits in "The Charter's Official Languages Provisions: The Implications of Entrenched Bilingualism" (1982) 4 Supreme Court L.R. 163 at 175 as follows:

The duality theory signifies that official-language minorities are not like other minorities.

The constitution grants special and additional protection to them with respect to those areas 
absolute minority rights under the duality provisions. The result is a more specific and limited meaning of minority rights under s. 27. For example, the natural nexus between s. 27's cultural protections and linguistic, educational and religious rights is artificially severed when these rights concern the official minority groups under the duality provisions. ${ }^{18}$ The potential incompatibility of s. 27 with absolute minority rights as a result of these constitutional limitations offers some insight for its interpretation. From this perspective it is argued that the operative or guiding principle of s. 27 is not "true" multiculturalism but rather "multicultural heritage" in the negative rights sense. The latter principle dictates that "culture" be given broad protection as a negative right. This definitional shrinkage of $\mathrm{s} .27$ as a negative right is much more conducive to a judicial approach. It is further contended that only when courts begin to embark upon a similar exercise will s. 27 have a legal significance and analytical framework comparable to other constitutional provisions.

\section{THE MEANING OF MULTICULTURALISM}

There is no definitive meaning of multiculturalism, culture or multicultural heritage. The purpose of this part is to explore various meanings that have been provided. This is done by briefly reviewing the origins of multiculturalism, the principles of multiculturalism in the context of minority rights ${ }^{19}$ and the multicultural approaches that have emerged.

of the constitution that reflect duality. Ethnic minorities will take the point hard, but the thesis of our new constitution is that, with respect to the language of government jobs, government services, religious instruction, schools and culture, anglophone and francophone minorities stand in a preferred position. The reason is wholly political. It is an attempt to forge a working reconciliation between Quebec and the rest of Canada.

For an account of the limits imposed on multiculturalism by Quebec's distinctiveness, special status and provincial powers (particularly over language) see DaRe, supra note 14.

Professor LeBel alludes to the artificiality of limiting the nexus between culture and language when pointing out in "Some Reflections on Section 27 of the Canadian Charter of Rights and Freedoms" (Speech given at the Colloquium of the Canadian Human Rights Foundation, Ottawa, 1985) [unpublished] that:

First, one cannot actually separate language from culture; and one notes that only two languages and two minorities who speak these languages are given a privileged position in Canada by virtue of the Constitution. Second, those whose mother tongue is neither English nor French are gradually integrated over time into one or the other of the two major Canadian communities, with all the attendant cultural absorption.

The Supreme Court of Canada has confirmed the artificial nature of severing language and culture in Mahe v. Alberta, [1990] 1 S.C.R. 342 [hereinafter Mahe]; and Quebec v. Ford, [1988] 2 S.C.R. 712. In Mahe, language was interpreted (ibid. at 362) as "part and parcel of the identity and culture of the people speaking it"; and in Ford (ibid. at 749) as a "means by which a people may express its cultural identity." Dickson C.J. (as he then was) went on to hold, for the Court in Mahe (ibid. at 369), that "in the interpretation of s. 23 [minority language education rights] I do not think it helpful in the present context to refer to either s. 15 or s. 27." Hosein is critical of this limited view of s. 27 and points out, supra note 8 at 613 , that if "language is considered to be so essential to the content of a particular culture, then $\mathrm{s}$. 27 should not be limited by the official language [or education] clauses of the Charter." Both Big M Drug Mart, infra note 42 and Videoflicks, infra note 45 , held that multiculturalism also includes religion.

See supra note 16 . The protections of equality and group maintenance are central to minority rights in a pluralist society. 
A starting point to understanding the multiculturalism principle in Canada is Volume IV of the Report of the Royal Commission on Bilingualism and Biculturalism, ${ }^{20}$ and the subsequent Multiculturalism Policy in 1971. The central theme enunciated was "multiculturalism within a bilingual framework." The 1971 Policy set out four objectives $^{21}$ and the ensuing debate over the meaning of multiculturalism made it clear that opinion was divided on the relative value of these different objectives.

Central to the debate is the concept of "culture." Howard Brotz has observed that multiculturalism cannot be evaluated unless one comprehends "the real meaning of the term culture underneath all the rhetorical ambiguities of current usage." ${ }^{22} \mathrm{He}$ defines the word "culture" as signifying a "way of life" for the community which is institutionally complete: "an organic whole ... rooted in the authentic life of a people seen as a community bound together by pervasive traditions and moral ties."23 Understood in this sense, Brotz denies that Canada possesses any cultural diversity at all. Members of all of Canada's ethnic collectivities, Brotz argues, aspire for exactly the same thing, a "bourgeois way of life." Brotz reduces the multicultural policy to one of little importance. Multiculturalism turns out to be nothing more than an "ethnic zoo" where one can sample "pizzas, wonton soup and 'kosher' style pastrami sandwiches. ${ }^{24}$

Brotz adopts a broad definition of "culture" in its absolute or "true" form. This view firmly places cultural protections in the wider context of minority rights and tends to link ethnic group maintenance with its "institutional completeness." This concept was first formulated by sociologist Raymond Breton in his study of immigrant communities in Quebec. ${ }^{25}$ Institutional completeness refers to the degree to which the ethnic community controls its own institutions: schools, media, voluntary organizations, churches, etc. Breton suggests that communities can vary considerably in their social and institutional organization. Institutional completeness would be most evident when the ethnic community could perform all services required by its members, but Breton admits that very few, if any, ethnic communities demonstrate full institutional

Canada, Royal Commission on Bilingualism and Biculturalism: The Cultural Contributions of the Other Ethnic Groups (Ottawa: Queen's Printer, 1970) vol. 4.

House of Commons Debates (8 October 1971) at 8581:

1. The Government of Canada will support all of Canada's cultures and will seek to assist, resources permitting, the development of those cultural groups which have demonstrated a desire and effort to continue to develop a capacity to grow and contribute to Canada, as well as a clear need for assistance.

2. The Government will assist members of all cultural groups to overcome cultural barriers to full participation in Canadian society.

3. The Government will promote creative encounters and interchange among all Canadian cultural groups in the interest of national unity.

4. The Government will continue to assist immigrants to acquire at least one of Canada's official languages in order to become full participants in Canadian society.

H. Brotz, "Multiculturalism in Canada: A Model" (1980) 6 Can. Pub. Pol. 41 at 41-42.

Ibid. at 42.

Ibid.

R. Breton, "Institutional Completeness of Ethnic Communities and the Personal Relations of Immigrants" (1964) 70:2 American Journal of Sociology 193. 
completeness. According to the concept of institutional completeness, ethnic identity would most likely be maintained if: (a) ethnic group members successfully resist assimilation; and (b) there is a high degree of organizational/institutional interdependence within the institutional framework of the ethnic community.

A strong proponent of this position is Professor J.E. Magnet. In interpreting s. 27 of the Charter, he thinks that due consideration should be given to institutional completeness or what he calls "structural ethnicity." He defines this concept as relating to the possibility of an ethnic group ensuring its survival through the development of necessary infrastructures. ${ }^{26}$

As is apparent from Magnet's stance, "true" multiculturalism emphasizes the "collective" dimension of minority rights; namely the preservation and promotion of the group's specific characteristics. This collectivism or collective approach is premised on the belief that it is through cultural communities that individuals define and develop their own individuality. Collectivism elevates group security and autonomy. It preserves those institutions through which minorities propagate their communities. It creates special limited autonomy for these groups by reserving power to them to manage or control certain institutions. This represents an expansive view of multiculturalism that has been encouraged in part by the group maintenance component articulated in the first objective of the 1971 Multiculturalism Policy.

The first policy objective seeks to encourage ethno-cultural groups' survival in Canada through government support of those ethnic groups which have demonstrated a desire to develop as distinctive cultural entities. Those who favour this objective emphasize the importance of ethnic communities to its individual members ${ }^{27}$ as well as to national unity. ${ }^{28}$ Responding to these views are opponents of the policy objective and the "collective" approach. They argue that the encouragement of ethnic diversity and cultural distinctiveness fosters ethnic separation and retention of traditional values. ${ }^{29}$ Under this view, the government's promotion of ethnic diversity impedes the development of national unity. The concern with the "collective" approach is the difficulty it poses for judicial interpretation in protecting individual rights, determining group "membership," and avoiding the "slippery slope" of policy-making. ${ }^{30}$

J.E. Magnet, "Interpreting Multiculturalism" in Multiculturalism and the Charter (Toronto: Carswell, 1987) 145 at 148. "Structural ethnicity," according to Magnet, relates to "the capacity of a group to perpetuate itself, control leakage, resist assimilation, and propagate its beliefs. It is not a matter of voluntary individual choice. Rather, it depends on the creation, by the group of an institutional infrastructure, to maintain the well-being of the group and nurture its selfjustification."

J. Bumet, "Ethnicity: Canadian Experience and Policy" (1976) 9:3 Sociological Focus 199 at 203. J.E. Magnet, "Collective Rights, Cultural Autonomy and the Canadian State" (1986) 32 McGill L.J. 171 at 175 .

J. Porter, "Ethnic Pluralism in Canadian Perspective" in Glazer \& Moynihan, eds., Ethnicity: Theory and Experience (Cambridge: Harvard University, 1975) at 267. More recently, see Bissoondath, supra note 10.

This will be discussed in Part III of the article. 
With regard to the second and third objectives of the multicultural policy statement, there seems to be less controversy. The second policy objective attempts to eliminate cultural barriers to full participation in Canadian society; the third seeks to promote creative encounters among Canada's ethnic groups. Both of the objectives appear to be designed to reduce racial/ethnic discrimination, to protect fundamental human rights of ethnic group "members" and to foster Canadian unity.

The emphasis of these two policy objectives is different from that of the first. One stresses the negative rights of non-discrimination or equality, the other the positive rights of group maintenance or survival. Magnet has summarized the former component of multiculturalism as "symbolic ethnicity." This view considers cultural heritage as a voluntary, psychological idea with the individual identifying with the traditions of a particular group. The identification process completes a person's sense of self or identity. ${ }^{31}$

This is a more limited definition of "culture." Cultural protections in the context of minority rights are viewed as supportive of equality, individual rights and liberal theory. The preservation of ethnic identity is viewed as a voluntary matter. The individual is recognized as having freedom of choice in whether or not to maintain his or her distinctive ethnic identity. For those individuals who decide to maintain their ethnic identity, membership in an ethnic group cannot be used as a grounds of discrimination. Each individual is to be treated equally, regardless of their ethnic membership or affiliation. This recognizes the fact that an individual may not feel very "ethnic" and may seek affiliation outside their ethnic group rather than within it. This view of multiculturalism protects the individual rights of members to freely make such a decision outside the collective pressures of their ethnic group.

The incorporated components of the multicultural policy as part of minority rights - freedom from discrimination and group maintenance - are central to an understanding of s. 27. That they provide different directions for multicultural rights in Canada is apparent. This definitional tension between individual and collective rights has also expressed itself in the Canadian Multiculturalism Act. ${ }^{32}$ A further source of ambiguity under the Act is the bilingual framework in which the Act and multiculturalism operate.

The fourth policy objective of the Multicultural Policy, linguistic assimilation, recognizes the preferred position of the English and French languages and that multiculturalism does not mean multilingualism. This is reflected under the duality

Supra note 26. Dickson C.J. (as he then was) adopted this approach to s. 27 in $R$ v. Keegstra, [1991] 2 W.W.R. 1 (S.C.C.), rev'g (1988), 43 C.C.C. (3d) 150 (Alta. C.A.), rev'g (1984), 19 C.C.C. (3d) 254 (Q.B.) [hereinafter Keegstra]. See infra note 56 and accompanying text.

S.C. 1988, c. 31. For example, ss. 3(1)(c) and (d) provide that the policy of the Government of Canada is to "promote the full and equitable participation of individuals and communities of all origins in the continuing evolution and shaping of all aspects of Canadian society and assist them in the elimination of any barrier to such participation"; and to "recognize the existence of communities whose members share a common origin and their historic contribution to Canadian society, and enhance their development." 
provisions of the Constitution. ${ }^{33}$ Section 27 is limited in this regard. The bilingual framework of the policy accords official recognition only to the linguistic rights of the Charter groups, while the linguistic rights of ethnic minorities are not recognized or guaranteed. This has not sat well with some multiculturalists. In their view, multiculturalism as a minority right, in the sense of maintaining viable ethnocultural communities, is meaningless without multilingualism. Some scholars have made the argument that it is appropriate to speak of language rights where an ethnic collectivity has the requisite population numbers to ensure the maintenance of the use of the language. Both Douglas and Kallen have contended that, where numbers warrant, constitutional guarantees for the protection and recognition of non-official languages should be afforded under s. $27 .{ }^{34}$ The dualist reality of Canada is quite different. The Constitution dictates that in public life and education, the French and English languages are equal and preferred over "other" languages.

This review of multiculturalism from the perspective of minority rights has left many questions unanswered about the principles of multiculturalism. The evolution from policy to legislation and constitutional entrenchment has not directed a more certain approach to s. 27. Part of the reason for this is the different emphasis placed on the components of the multicultural policy which in turn has led to different multicultural approaches. The extent to which $\mathbf{s .} 27$ constitutes a minority right which embraces the concepts of equality, non-discrimination and individual rights on the one hand, and group maintenance, institutional completeness and collective rights on the other, therefore, remains an open question. Another explanation for the uncertainty relates to the artificial limits imposed on multiculturalism by other constitutional principles, such as dualism. A possible resolution of these issues will be discussed in Part IV where an approach to $\mathrm{s}$. 27 is advanced. However, this is preceded by a review of the limited jurisprudence under the provision which may provide some guidance towards the resolution of these issues.

\section{SOME JUDICIAL APPROACHES TO SECTION 27}

Judicial approaches to s. 27 have ranged from ambivalence to avoidance. Some exceptions can be found in the jurisprudence, however, and one of the more sophisticated applications of s. 27 was advanced by Dickson C.J. (as he then was) on behalf of the majority in Keegstra. ${ }^{35}$ While the treatment of s. 27 may seem rather timid in the case, it is in fact quite progressive given the limited nature of the decisions that came before it. The decision cites previous jurisprudence under the section, summarizes the different judicial applications to date and, more importantly, signals the beginning or early stage of a multicultural approach or framework. Whether the courts

$3 \quad$ For example, ss. 16 to 23 of the Charter deal with minority language and education rights.

34 R.A.A. Douglas, cited in Leavy, Working Paper for a Conference on Minority Rights (York University, October 1979) at 11-14; Kallen, "Multiculturalism, Minorities and Motherhood: A Social Scientific Critique of Section $27^{n}$ in Multiculturalism and the Charter (Toronto: Carswell, 1987) 123. 
pick up this signal and take a more active role in shaping s. 27 remains to be seen. ${ }^{36}$ What follows, therefore, is a selective review of the court's treatment of this underdeveloped section.

If Keegstra represents a watershed in the judicial development of a multicultural approach under s. 27, then the decision warrants closer scrutiny. The central question was whether the criminalization of hate propaganda under the Criminal Code ${ }^{37}$ constituted a violation of freedom of expression under s. 2(b) of the Charter. Quigley $J$. of the Court of Queen's Bench of Alberta held that the prohibition did not violate the Charter since hate propaganda did not fall within the ambit of protected speech under s. 2(b) of the Charter. Sections 15 (equality rights) and 27 were relied upon by Quigley $\mathrm{J}$. in reaching the conclusion that hate propaganda was not protected speech. Both sections were consequently interpreted as "squeezing out" hate propaganda from protected speech. ${ }^{38}$

On appeal, Kerans J.A., writing for the Alberta Court of Appeal, rejected this finding, quashed the conviction and declared the hate propaganda provisions to be unconstitutional. Not only were the provisions held to be in contravention of s. 2(b) of the Charter, they were not saved by s. 1 as "reasonable limits." Furthermore, ss. 15 and 27 were used explicitly as part of the $s .1$ analysis, and not as part of the analysis of the s. 2 right, as applied by Quigley J. The Court of Appeal further concluded that competing Charter values, such as equality and multiculturalism, should be balanced under s. 1. Despite the application of ss. 15 and 27 to the s. 1 analysis, the Court still rejected as "reasonable limits" the hate propaganda provisions. ${ }^{39}$

On appeal, the Supreme Court of Canada held that racial propaganda was protected speech under s. 2(b) of the Charter and that the competing values of equality and multiculturalism in this case were best balanced under s. 1. However, unlike the Court of Appeal, the Supreme Court held that the hate propaganda provisions constituted "reasonable limits" under s. 1. Section 27 was significant in the $\mathbf{s} .1$ finding since hate propaganda undermined the target group, its individual members and cultural pluralism, according to the Court. The dictum of Cory J.A. (as he then was) in $R$. v. Andrews and Smith was cited with approval by the Supreme Court of Canada to support its interpretation of the role of s. 27 under s. 1: "Multiculturalism cannot be preserved let alone enhanced if free rein is given to the promotion of hatred against identifiable cultural groups." 40

If the decisions in Fosty and Bell, supra note 2, are an early indication, the prospects are not positive.

Criminal Code, R.S.C. 1985, c. C-46, s. 319(2).

Supra note 31 at 254 (Alta. Q.B.).

Supra note 31 at 168 (Alta. C.A.).

Supra note 31 at 51 (S.C.C.), citing (1988), 65 O.R. (2d) 161 at 181. Cory J.A.'s decision continued (although not cited by the Supreme Court): "What a strange and perverse contradiction it would be if the Charter was to be used and interpreted so as to strike down a law aimed at preserving our multicultural heritage by limiting in a minimal and reasonable way freedom of expression. This would be to construe the Charter in a manner prohibited by s. 27." (ibid. at 181). 
Writing for the majority in Keegstra, Dickson C.J. went beyond mere flippant treatment of s. 27. The more significant case law under the provision was cited and the preliminary outline to a multicultural approach or framework was formulated. This treatment of $s .27$ is now reviewed more carefully.

\section{A. LEADING CASE LAW UNDER SECTION 27}

The leading jurisprudence under the multicultural provision was cited by the Court in the following terms:

This court has where possible taken account of 5.27 and its recognition that Canada possesses a multicultural society in which the diversity and richness of various cultural groups is a value to be protected and enhanced. Section 27 has therefore been used in a number of judgments of this court, both as an aid in interpreting the definition of Charter rights and freedoms (see, e.g., Big M Drug Mart, ... Edwards Books, ... and Andrews v. Law Soc. of B.C. ...) and as an element in the s. 1 analysis (see, e.g., Edwards Books ...)."1

In the Big M Drug Mart ${ }^{42}$ case, the Supreme Court of Canada considered the constitutional validity of the federal Lord's Day $A c t,{ }^{43}$ and concluded that its provisions, mandating Sunday retail closing, violated the freedom of religion guarantee under s. 2(a) of the Charter. Writing for the majority, Dickson J. (as he then was) referred to s. 27 in his analysis of s. 2(a) in the context of protecting minorities from majoritarian coercion. He found that "to accept that Parliament retains the right to compel universal observance of the day of rest preferred by one religion is not consistent with the preservation and enhancement of the multicultural heritage of Canadians." ${ }^{44}$

In Edwards Books ${ }^{45}$ the Supreme Court also used s. 27 as an interpretive guide to s. 2(a) of the Charter. The multicultural provision was similarly found to support a meaning of freedom of religion which protected minority interests from majoritarian coercion. The Court held that the Provincial Sunday closing legislation in question imposed a statutory disadvantage on those who did not observe the Sunday Sabbath, by making it more expensive for them to practice their religion. Therefore, the provision was in breach of s. 2(a) of the Charter. However, given the social rather than religious purpose of the legislation, the exceptions provided for small businesses, and the relative protection of minority interests, the legislation was nonetheless upheld under s. 1 of the Charter.

Wilson J., dissenting, agreed with the Court of Appeal's approach, including its treatment of s. 27, to shield all those who celebrated a non-Sunday Sabbath from the

$4 \quad$ Supra note 31 at 50 (S.C.C.).

$42 \quad R$ v. Big M Drug Mart, [1985] 1 S.C.R. 295.

43 R.S.C. 1970 , c. L-13.

$44 \quad$ Supra note 42 at 337-38.

45 R. v. Edwards Books and Art Ltd., [1986] 2 S.C.R. 713 [hereinafter Edwards Books], rev'g in part (1984), 48 O.R. (2d) 395 (C.A.) (sub nom R v. Videoflicks) [hereinafter Videoflicks]. 
application of the Act. She declined to uphold the statute under s. 1. Wilson J. argued that the exemption allowed some but not all of the members of Saturday-observing minorities to do business on Sundays. Reference was made to Professor Tarnopolsky's (as he then was) argument that the Charter protects group rights as well as individual rights. ${ }^{46}$ This led Wilson J. to assert that when the Charter protects group rights such as freedom of religion, it protects the rights of all members of the group. Otherwise, she continued, if the selective nature of the exemption remained in force it would introduce "an invidious distinction into the group and sever the religious and cultural tie that binds them together. ${ }^{47}$ Therefore, 5.27 expressly precluded the Court from interpreting $\mathbf{s .} 1$ as relevant to the statutory exemption. Unlike the majority, Wilson J. used s. 27 as part of the s. 1 analysis by injecting group "values" or "rights" into the analysis.

This opinion that the exemptions did not go far enough to protect minorities was similar to that of the Ontario Court of Appeal. Writing for the Court, Tarnopolsky J.A. held that the legislation did contravene the Charter to the extent that it failed to provide exemptions for retailers who for sincere religious reasons were required to close their businesses on a day other than Sunday. In reaching this decision, Tarnopolsky J.A. called for judicial activity rather than avoidance under s. $27 .^{48}$

His Lordship traced the history of the section by referring to the stated objectives of the 1971 Multiculturalism Policy, discussed earlier. He also placed the provision in the context of international minority rights. Specifically, with reference to Article 27 of the International Covenant on Civil and Political Rights, ${ }^{49}$ Tarnopolsky J.A. concluded:

The article referred to is W.S. Tamopolsky, "The Equality Rights in the Canadian Charter of Rights and Freedoms" (1983) 61 Can. Bar Rev. 242. Professor Tamopolsky distinguished individual and collective rights at $259-60$ as follows:

There are at least two fundamental distinctions which must be emphasized for the sake of clarity. The first is that an assertion of an individual right emphasizes the proposition that everyone is to be treated the same regardless of his or her membership in a particular identifiable group. The assertion of group rights, on the other hand, bases itself upon a claim of an individual or a group of individuals because of membership in an identifiable group ... this leads to the second distinction ... the guarantee of an individual right like free expression essentially requires the non-interference of the state. A group right like language rights, on the other hand, requires positive governmental action. Supra note 45 at 808 (S.C.C.).

48 In $R$ v. Videoflicks, supra note 45 at 426 , Tarnopoisky J.A. made the following remarks in connection with s. 27: "It is not for the courts to express their opinion concerning the justification for this constitutional entrenchment of a policy of pluralistic cultural preservation and enhancement. Nor should the courts avoid giving it any significance. It is merely our duty to try to define how the Charter shall be interpreted in light of this provision." practise their own religion, or to use their own language." 
S. 27 determines that ours will be an open and pluralistic society which must accommodate the small inconveniences that might occur where different religious practices are recognized as permissible exceptions to otherwise justifiable homogeneous requirements. ${ }^{\text {so }}$

In this case the homogeneous requirement or dominant norm of Sunday closing made religious practice for the minority more difficult and costly and, according to the Court, did not preserve or enhance that "part of one's culture which is religiously based" under s. $27 . .^{51}$

Besides religion, s. 27 has also played a role in the interpretation of s. 15 "equality rights." In Andrews, ${ }^{52}$ the Supreme Court of Canada used s. 27, along with other Charter provisions, to support the view that the Charter's equality guarantee does not mandate identical treatment and that certain distinctions between individuals and groups (i.e. affirmative action programs for some groups under s. 15(2)) are recognized. As McIntyre J. pointed out:

It must be recognized ... that the promotion of equality under s. 15 has a much more specific goal than the mere elimination of distinctions. If the Charter was intended to eliminate all distinctions, then there would be no place for sections such as 27 (multicultural heritage) ... and other such provisions designed to safeguard certain distinctions. ${ }^{53}$

Section 27 therefore encourages an approach to s. 15 which places due emphasis on individual and group distinctiveness as a component of interpretation, according to the Supreme Court of Canada.

Sections 15 and 27 have also been relied upon to challenge the duality provisions. The preferred status of the official minority groups, however, has not changed. With regard to religious, ${ }^{54}$ educational $^{55}$ and linguistic ${ }^{56}$ protections, the courts have

Supra note 45 at 428 (Ont. C.A.).

lbid.

Supra note 3. For the argument that Andrews was subsequently limited in $R$. v. Turpin, [1989] 1 S.C.R. 1296, see Gibson, "The Deferential Trojan Horse," supra note 4 at 437.

Andrews, ibid. at 171.

In Reference re Bill 30, An Act to Amend the Education Act, [1987] 1 S.C.R. 1148 at 1197-98, Wilson J. stated that:

[T]he special treatment guaranteed by the constitution to denominational, separate or dissentient schools, even if it sits uncomfortably with the concept of equality embodied in the Charter because not available to other schools, is nevertheless not impaired by the Charter... These educational rights, granted specifically to the Protestants in Quebec and the Roman Catholics in Ontario, make it impossible to treat all Canadians equally. The country was founded upon the recognition of special or unequal educational rights for specific religious groups in Ontario and Quebec. The incorporation of the Charter into the Constitution Act, 1982, does not change the original Confederation bargain.

This position that ss. 15 and 27 do not trump denominational educational rights was recently applied in Adler v. Ontario (1994), 19 O.R. (3d) I (Ont. C.A.) [hereinafter Adler].

In Mahe, supra note 18 at 369 Dickson C.J., for the courh, stated that:

Section 23 provides a comprehensive code for minority language educational rights; it has its own internal qualifications and its own method of internal balancing. A notion of equality between Canada's official language groups is obviously present in s. 23. Beyond this, 
ensured that the dualist nature of Canada remains intact despite these challenges.

In Keegstra, the other important role designated to s. 27 was in conjunction with s. 1. Section 1 focuses on whether the violation of a Charter right nonetheless constitutes a "reasonable limit prescribed by law as can be demonstrably justified in a free and democratic society." Limits that have an undue or adverse impact on Canada's multicultural heritage or practices are potentially unreasonable under s. 1. Conversely, limits favourable to multicultural heritage are potentially reasonable under $\mathrm{s}$. 1 . Thus, as examined earlier, Wilson J.'s dissent in Edwards Books concerned s. 27's second stage application; and in Keegstra itself, s. 27's second stage application was significant in the Court's characterization of the hate propaganda provisions as "reasonable limits."

Following the citation of these leading decisions under s. 27, Dickson C.J. in Keegstra turned to a closer consideration of a multicultural approach or framework. Given the limited treatment of 5.27 in these leading cases, a closer consideration of the provision represents a welcomed change. Despite Tarnopolsky J.A.'s call for judicial activity under s. 27 in Videoflicks, and Dickson C.J.'s affirmation in Keegstra that the provision has been used in several decisions, the treatment of s. 27 in these so-called leading decisions has been rather meagre. Perhaps telling is the tendency in some decisions $^{57}$ to cite s. 27 and then virtually ignore the provision. Another tendency to lump s. 27 together with other Charter provisions, such as in Andrews, may also encourage this frugal treatment. Section 27's eclipse by the duality provisions as apparent in Mahe has also limited its consideration. Finally, as apparent from the approaches in Edward Books and Andrews, the uncertainty of s. 27's status as a minority right, with no resolution of the provision's inherent contradictions or tensions (i.e. equality vs. group maintenance, non-discrimination vs. institutional completeness, individual rights vs. collective rights) may account for some of the judicial avoidance. A closer consideration of 5.27 was indeed necessary.

\section{B. THE BEGINNINGS OF AN APPROACH UNDER SECTION 27(?)}

If an approach to s. 27 was suggested in Keegstra it was a very tentative and preliminary one. Chief Justice Dickson made these brief statements:

I am of the belief that $\mathrm{s} .27$ and the commitment to a multicultural vision of our nation bears notice in emphasizing the acute importance of the objective of eradicating hate propaganda from society.

however, the section is, if anything, an exception to the provisions of ss. 15 and 27 in that it accords these groups, the English and the French, special status in comparison to all other linguistic groups in Canada.

The Ontario Court of Appeal in Adler, supra note 54, recently adopted this position in protecting minority language education rights from ss. 15 and 27 challenges. equality of status of English and French until such time as a similar status could be attained for all the other languages spoken in Canada. This would derogate from the special status conferred on English and French in s. 16." 
Professor Joseph Magnet has dealt with some of the factors which may be used to inform the meaning of s. 27, and of these I expressly adopt the principle of non-discrimination and the need to prevent attacks on the individual's connection with his or her culture, and hence upon the process of selfdevelopment.... Indeed, the sense that an individual can be affected by treatment of a group to which he or she belongs is clearly evident in a number of other Charter provisions not yet mentioned, including ss. 16 to 23 (language rights), s. 25 (aboriginal rights), s. 28 (gender equality) and s. 29 (denominational schools)..$^{\text {s8 }}$

The Court's hesitation in conceding collective rights under s. 27 is indicative of its status as a minority right. This definitional shrinkage is indeed telling.

As discussed earlier, Professor Magnet suggests that s. 27 must be analyzed by giving due consideration to structural ethnicity, as opposed to symbolic ethnicity. The former concept relates to collective rights and the possibility of a group or community ensuring its survival through the development of necessary infrastructures. The latter defines ethnicity in individual rights terms and by reference to psychological criteria and cultural identity. For Professor Magnet the reference to multicultural heritage "embraces institutional structures as well as the psychological encouragement of symbolic ethnicity." ${ }^{19}$ This means that the preservation of a multicultural heritage "would require an institutional infrastructure through which the group would act."100

There are several obstacles to Magnet's approach however, and these may explain the Court's hesitation towards adopting it in interpreting s. 27. First, the case law dealing with collective rights is not altogether supportive. Indeed, some judicial approaches have been quite hostile to the view of embracing collective rights. ${ }^{61}$ The second obstacle to the "collective" approach is the "slippery slope" of judicial policymaking. How far should the judiciary go towards accommodating ethnic groups under s. 27? Should the provision be interpreted to accommodate the claims of relative autonomy by other communities besides official minorities? Is there a need for interpreting and finding under s. 27 linguistic rights for other communities in Canada? In addition to a guarantee of linguistic rights, including the right of education, should the multicultural provision be interpreted as providing these communities with tools to develop culturally as they see fit and to protect themselves against assimilation? The implications of a "collective" approach therefore may have encouraged courts to avoid its adoption.

Keegstra, supra note 31 at 50-51 (S.C.C.) [emphasis added]. Magnet, supra note 26 at 150 .

Ibid.

This was apparent in Chief Justice Deschênes' judgement of first instance in A.G. Quebec v. Quebec Assn. of Protestant School Bds. (1982), 140 D.L.R. (3d) 33 (Que. S.C.) in relation to s. 23 of the Charter. He stated at 64:

Quebec's argument is based on a totalitarian conception of society to which the Court does not subscribe. Human beings are, to us, of paramount importance and nothing should be allowed to diminish the respect due to them. Other societies place the collectivity above the individual. They use the Kolkhoze steamroller and see merit only in the collective result even if some individuals are left by the wayside in the process. This concept of society has never taken root here ... and this Court will not honour it with its approval. 
One may also question the desirability of every group being entitled to the public maintenance of its own language through government and the school system. Furthermore, the basic concept of a collectivity may be questioned. How does one determine membership in a group? Does it really make sense for Canadians to divide themselves into different collectivities and have a plethora of different rights under the Constitution? Is it really possible to promote national unity and harmony in Canada if each group is preoccupied with: (a) determining who is and who is not a member of a particular collectivity; (b) securing a whole set of special rights for that group; and (c) promoting group differences? Perhaps for these reasons the Supreme Court of Canada has avoided the "slippery slope" of a "collective" approach under s. 27.

The final obstacle is a preference for individual rights and liberal theory. The Court in Keegstra favoured a more individualist theory of rights under s. 27. The express adoption of equality, non-discrimination and individual rights as elements of 5.27 clearly places the provision as a minority right within the ambit of liberal theory. The liberal individualist approach to multiculturalism has a precise definition of the recipient of multicultural rights; namely, the individual. This view supports the right of every individual to freely associate with any other person or group to maintain and develop any cultural tradition the individual considers appropriate. In this regard, "multicultural heritage" supports and promotes individual self-development. Dickson C.J. recognized this when he attributed self-identity, respect and worth to cultural membership; and, given the importance of such membership to the individual, he concluded that the option to pursue one's heritage should be equally available, should not be a ground for discrimination and should not be undermined by direct (i.e. on the individual) or indirect (i.e. on the group) attacks. ${ }^{62}$ Under this approach the Court avoided some of the more difficult questions raised by the "collective" approach mentioned above.

Whether Keegstra represents a watershed in the judicial development of s. 27 is debatable. It is suggested here that a very preliminary multicultural approach or framework may be extracted from the decision. The Supreme Court's direction under the multicultural provision is in the tradition of liberal theory and individual rights. This provides some guidance for the approach to $s .27$ which will now be formulated.

\section{A MULTICULTURAL APPROACH UNDER SECTION 27}

Any approach to s. 27 has to cope with a text, hierarchical status and liberal individualist perspective which limit its interpretation as a minority right. All these factors combine to deliver something much less than "true" multiculturalism under $\mathbf{s .}$ 27 , and it is within this context that the preservation and enhancement of the "multicultural heritage of Canadians" must be understood. The textual direction of s. 27 is first examined. 


\section{A. TEXTUAL LIMITS OF SECTION 27}

In this regard, s. 43 of Quebec's Charter of Human Rights and Freedoms ${ }^{63}$ provides an interesting comparison. It allows that "persons belonging to ethnic minorities have a right to maintain and develop their own cultural interests with the other members of their group." Section 43 defines the recipients of its rights as "persons belonging to ethnic minorities," while s. 27 speaks of "the multicultural heritage of Canadians." Section 43 defines entitlement as "a right to maintain and develop their own cultural interests, ${ }^{164}$ while s. 27 refers to entitlement only by the Charter being "interpreted in a manner consistent with the preservation and enhancement" of the recipients above. Finally, while s. 43 categorizes the right as one to be maintained and developed "with the other members of their group,"65 s. 27 is silent on this "collective" issue.

The differences arise from the textual precision of s. 43. It provides more precise direction to the courts as to the recipients of the entitlement, the nature of the entitlement and the category of rights under the cultural protection. For example, the recipients of the cultural guarantees are specified as "persons belonging to ethnic minorities," rather than the amorphous "multicultural heritage of Canadians." Entitlement to the cultural protections is defined as a substantive "right" rather than a vague "rule of interpretation." Finally, the right is categorized as a group or collective one compared with a text which seems silent on the issue. These textual imprecisions may explain some judicial hesitation under s. 27, but it is argued here that they should not hinder the development of a multicultural approach to $\mathrm{s} .27$.

First, s. 27's cultural protections apply to "all Canadians" rather than just "ethnic groups." This general application dispenses with the difficult judicial task of identifying "ethnic" groups and determining individual membership. Indeed, s. 27 has been applied in conjunction with the duality provisions to advance the rights of the official minority groups. For example, the Ontario Court of Appeal in Reference Re Education Act of Ontario and Minority Language Educational Rights ${ }^{66}$ interpreted s. 27 as a guarantee of culture to all Canadians, including those in the English and French speaking communities. This indicates that the recipients of s. 27 protections are "all Canadians."

Secondly, s. 27 is a "rule of interpretation" rather than a "substantive" right, but courts should not use this designation of entitlement as an excuse for avoiding the provision. In some decisions this practice has been followed. ${ }^{67}$ There is no merit to the pedantic distinction made between "values" and "rights" or a "rule of interpretation" and a "substantive right," which some courts have accepted. However one interprets the multicultural provision, "rights" will be affected by judicial pronouncements under the provision. A court can rule that the provision grants a right to an individual or group, or it can "interpret" the constitutional "value" underlying the provision so as to grant

\footnotetext{
R.S.Q. 1977 , c. C-12.

[Emphasis added].

[Emphasis added].

(1984), 10 D.L.R. (4th) 491 (Ont. C.A.).

See e.g. Bell, supra note 2; Fosty, supra note 2.
} 
the right to an individual or group. Both decisions involve acts of interpretation and both permit protection of rights. This may take place at either stage of constitutional interpretation: as an adjunct to the right in question and as part of the analysis in the determination of an infringement of the right, or as a sui generis addendum to a "reasonable limits" analysis pursuant to $\mathrm{s}$. 1 of the Charter. The two approaches were apparent in Keegstra and Edwards Books. In Keegstra, Quigley J. used s. 27 as part of the stage one "rights" analysis whereas Dickson C.J. applied the provision to inject multicultural "values" in the second stage analysis. Under both approaches the hate propaganda provisions were upheld, with multicultural rights or values taking precedence over freedom of expression. Similarly, in Edwards Books, the two approaches were canvassed, with Dickson C.J. applying s. 27 to the stage one "rights" analysis and Wilson J., in dissent, introducing multicultural "values" to the "reasonable limits" analysis.

Thirdly, s. 27 introduces individual and collective values into the equation of judicial interpretation. Keegstra and Edwards Books are again relevant. In Keegstra, the collective value of the target group's maintenance triumphed over a traditional individual right - freedom of expression. In Edwards Books, Wilson J., dissenting, applied s. 27 in a collective manner in the s. 1 analysis to protect "the religious and cultural tie that binds [the group] together."${ }^{168}$ However, after Keegstra, these collective values or rights under s. 27 have to be understood in the context of a liberal individualist perspective.

\section{B. SECTION 27, MINORITY RIGHTS AND THE LIBERAL INDIVIDUALIST APPROACH}

The liberal perspective of minority rights concentrates on equality, nondiscrimination and individual rights. Applied to s. 27, equality of individuals suggests the prohibition of all discrimination on grounds related to culture. The definition of "multicultural heritage" is significant in this regard. Also relevant is s. 27's sister provision under the Charter, the s. 15 equality right. Cultural protections, in the negative rights sense, have achieved almost universal recognition and Capotorti has described the proximate relationship between cultural plurality and equality as follows:

[T]he effective implementation of the right of persons belonging to ethnic, religious or linguistic minorities to enjoy their own culture, to profess and practice their own religion and to use their own language requires, as an absolute pre-condition, that the principles of equality and of nondiscrimination be firmly established in the society in which those persons live. ${ }^{69}$

An absolute pre-condition to s. 27's application is an interpretation embracing the principles of equality and of non-discrimination. Support for this perspective is further argued by revisiting Andrews and collectivism as discussed earlier. A multicultural approach will now be advanced.

69 Supra note 15 at 54 [emphasis added]. 
Formulating an approach to $\mathrm{s} .27$ necessarily means taking a position with regard to the "fluid" concepts of "culture" and "multicultural heritage." From the outset it is suggested that "true" multiculturalism is not mandated by s. 27. "Multicultural heritage" is not analogous to group maintenance, institutional completeness and collective rights. For textual, ${ }^{70}$ theoretical ${ }^{71}$ and political ${ }^{72}$ reasons the courts have properly shied away from this interpretation of s. 27. If multiculturalism turns out to mean a "community of communities," then this will be achieved through political expediency rather than judicial interpretation.

More conducive to a judicial approach is a view of $s .27$ which places the individual and collective elements of multiculturalism within a framework of liberal individualism. Section 27's interpretation is facilitated if viewed as a shield rather than a sword; a negative rather than positive right; or as protecting rather than promoting, at the individual and group level, cultural beliefs, practices and transmissions from discrimination. "Discrimination" and "culture" are terms which should receive broad judicial definition under this approach so as to cast a wide net under s. 27 protections. "Culture" includes the elements of language, education, religion, morals, customs and so on. "Discrimination" should also be defined broadly as it was in the Andrews decision, to be discussed below. However, "multicultural heritage" and its "preservation" and "enhancement" should also be interpreted as an individual, voluntary and personal matter. From this perspective the judicial function is limited to protecting the individual practice of multicultural heritage. In most instances this protection will be achieved under equality, non-discrimination and individual rights; $s .15$ is significant

For the imprecise text of s. 27, see supra note 63 and accompanying text.

For the concerns regarding individual rights, see supra note 61 and accompanying text. For the concerns of judicial policy making, see supra note 61 and accompanying text. In $R$ v. W.H. Smith Lld., [1983] 5 W.W.R. 235 at 258-59 (Alta. Prov. Ct.), Jones Prov. J. offered a broad definition of "culture" and a rather progressive interpretation of s. 27, particularly for an early Charter decision. The concept of "culture" is central to the multicultural principle, yet few judges dealing with s. 27 have attempted to define the concept. His Honour Judge Jones remarked as follows:

In requiring the Charter to be interpreted in a manner consistent with the preservation and the enhancement of the multicultural heritage of Canadians, the section, in my opinion, directs that a measure of equal treatment be dispensed when interpreting any problem involving the Charter and a problem involving multicultural considerations. I have been unable to find any written authority considering s. 27. I have found several definitions of "culture", the noun upon which the adjective "multicultural" is based. No definition appears to be more appropriate than one contained in Webster's Third New International Dictionary (G \& C Merriam Company) (1964) wherein "culture" is defined as inter alia "5a: the total pattern of human behaviour and its products embodied in thought, speech, action, and artifacts and dependent upon man's capacity for learning and transmitting knowledge to succeeding generations through the use of tools, language, and systems of abstract thought b: the body of customary beliefs, social forms and material traits constituting a distinct complex of tradition of a racial, religious, or social group ... that complex whole that includes knowledge, belief, morals, law, customs, opinions, religion, superstition, and art..." The same dictionary defines "heritage" as "something transmitted by or acquired from a predecessor."

He also recognized the hybrid nature or the "individual" and "collective" dimensions of the multicultural principle when interpreting s. 27 as directing a "measure of equal treatment" and recognizing the importance of "diverse cultural backgrounds." 
in this regard. However, for those indirect attacks on individual multicultural practices where the primary target is the group, as in Keegstra, judicial protection at the group level will also have to be considered. Again, s. 15 is relevant to this analysis.

Section 15 is one of the most important guarantees in the Charter for the purpose of protecting the multicultural heritage of Canadians, and its application in Andrews suggests a more expansive role for $\mathrm{s} .27$ than most courts have yet to concede. Indeed, the wording of $s .15^{74}$ can be interpreted as recognizing and supporting the dual nature of the multicultural principle so as to prevent discrimination while still allowing for distinctiveness among groups or individuals.

As discussed earlier, not all legal distinctions are discriminatory. Section 27 safeguards certain distinctions based on cultural diversity. McIntyre J. held in Andrews that identical treatment can lead to serious inequality if not remedied by way of government measures. Subsection 15(2) provides a constitutional mandate for such measures. Read with s. 27, the provision allows government to provide special measures or programs for some groups or communities to ensure retention of their cultural heritage, language heritage and to overcome disadvantages arising from past discrimination. However, the promotion of these positive measures or collective rights originates with government, not the judiciary; and the judicial function under s. 27 is limited in the negative rights sense.

It is in this sense that the court should be active and progressive under s. 27. Sections 15 and 27 dictate that "culture" in general be given broad protection as a negative right so as to include protections at the individual and group level. Several elements of "culture" are part of the enumerated protections of s. 15, such as "race, national or ethnic origin, colour, religion." Furthermore, the Supreme Court in Andrews made it clear that under the "enumerated and analogous grounds" approach, certain grounds not listed in s. 15, such as other elements of culture that are analogous in nature to those listed, qualify for protection. These unlisted grounds of protection exist for the benefit of "discrete and insular minorities," which arguably include cultural minorities. This approach significantly broadens the scope of cultural protections to embrace the many elements of culture noted above, such as unofficial languages, education, customs, traditions, etc. Discrimination based on these enumerated and analogous cultural grounds thus falls within the scope of the protections.

The concept of "discrimination" is also central to the cultural protections. In Andrews it received a broad definition, further indicating the strength of $s .27$ as a negative right.

Section 15 of the Charter provides as follows:

(1) Every individual is equal before and under the law and has the right to the equal protection and equal benefit of the law without discrimination and, in particular, without discrimination based on race, national or ethnic origin, colour, religion, sex, age or mental or physical disability.

(2) Subsection (1) does not preclude any law, program or activity that has as its object the amelioration of conditions of the disadvantaged individuals or groups including those that are disadvantaged because of race, national or ethnic origin, colour, religion, sex, age or mental or physical disability. 
"Discrimination" is defined as practices or attitudes that have the effect of limiting an individual's or a group's right to the opportunities generally available because of attributed characteristics. ${ }^{75}$ This definition includes distinctions based on individual or group characteristics, whether intentional or not, which have the effect of limiting or disadvantaging the particular victim. The broad definition of "discrimination" significantly expands the application of $s$. 27 to include, for example, protections against linguistic discrimination (e.g. an unofficial language being discriminated against in an employment context unless knowledge of an official language is a bona fide occupational requirement); religious discrimination (e.g. mandatory dress codes which contradict religious wardrobe, or mandatory holidays that penalize religious observance); and educational discrimination (e.g. mandatory school practices which compromise traditional cultural values).

The broad meanings of "culture" and "discrimination" direct the judiciary to play an active role in shaping s. 27 as a negative or equality right. However, even in this sense, s. 27 is limited as a minority right since it operates within a hierarchy of constitutional values.

\section{SECTION 27'S HIERARCHICAL STATUS}

For political reasons, multiculturalism as a constitutional value of interpretation under s. 27 is secondary to the preferred status of dualism under the duality provisions. The secondary status of multiculturalism is of course inconsistent with equality, and, accordingly, s. 27 is limited even as a negative right. ${ }^{76}$ This has led to different suggestions of how to achieve real equality, there being at one end the proposal to abolish this hierarchy, ${ }^{77}$ and at the other the proposal to entrench collective linguistic, religious and educational rights for ethnic groups. ${ }^{78}$ However, this accommodation of multiculturalism will occur at the political level. ${ }^{79}$

At the judicial level, the response to these concerns may be to view s. 27 as part of an evolving policy. The Supreme Court has had the opportunity of interpreting constitutional provisions entrenching evolving policies with regard to s. 16 of the Charter and official bilingualism, and has concluded that "a principle of growth or development exists in s. 16, a progression towards an ultimate goal. Accordingly, the

Andrews, supra note 3 at 174 .

For a full account of the relationship between equality and dualism, see M. Bastarache, "Dualism and Equality in the New Constitution" (1981) 30 U.N.B.L.J. 27; see also Magnet, supra note 17. Supra note 8. Hosein argues that Canada is better viewed as a "pioneer" society without "founding peoples" and group hierarchies so that multiculturalism can actually achieve equality for all Canadians.

Kallen, supra note 34 . Kallen argues at 127 that, based on the "premises and requirements of an egalitarian ideal of multiculturalism, the provisions of the Charter are weak [with] the most serious omission the lack of specified protections for the collective rights of all Canadian ethnic communities. Overall, it perpetuates the established ethnic hierarchy..." [emphasis added].

R. Simeon, "Meech Lake and Visions of Canada" in Competing Constitutional Visions (Toronto: Carswell, 1988) 299. Simeon points out at 303 that the long-term potential of the reorientation of multiculturalism is great but it will "occur from the bottom up, and be much more manifest in some provinces and cities than others; hence it will probably be facilitated by federalism..." 
question will always be - where are we currently on the road to bilingualism and is the impugned conduct in keeping with that stage of development." ${ }^{80}$ The same question may be asked with regard to the multicultural policy under s. 27.

\section{CONCLUSION}

The response advanced here is that $\mathbf{s .} 27$ is limited as a minority right. For one, it is limited by a text which is rife with uncertainty and fails to entrench positive or collective rights. In addition, it is limited by a body of case law which recognizes the individual dimension of the provision and further restricts s. 27 as a negative or equality right under dualism. Finally, it would be unrealistic to rely on the courts as the primary regulator of community relations or as a primary promoter of cultural diversity because, as Magnet points out, the courts "lack the proper orientation, sophistication and resources to make out of collective rights cases all that the proponents of collective rights expect, but seldom, if ever, receive."18

Despite these limits, s. 27 is an important cultural protection which deserves closer judicial consideration. This has been seriously lacking for various reasons. A characterization of 5.27 as a negative right protecting individuals and groups against discrimination and advancing equality would seem more conducive to a judicial approach. In Keegstra, Dickson C.J. (as he then was) signalled an expansive interpretation of s. 27 as a negative right. Whether this approach will be adopted, thereby reversing the trend of judicial avoidance under the provision, remains a matter of speculation. More certain is the need to develop s. 27 beyond its embryonic stage, and to achieve this, a multicultural approach under the provision ought to be forthcoming. 